\title{
Sacral Art as Sociocultural Model
}

\author{
Irina Ryzhkova \\ Russian State Social University \\ Moscow, Russia \\ e-mail: daira11@yandex.ru
}

\begin{abstract}
The main objective of this article is an explanation of the role of sacral art in a general cultural background. The purpose is to reveal the traits defining value of sacral art in the formation of a sociocultural model of society.
\end{abstract}

Keywords-sacrality; sacral art; sociocultural model; ethnocultural identity

\section{INTRODUCTION}

Among many factors forming domestic culture besides the rich history, geography and environment and domestic and cultural traditions a special place is taken by the sphere of spiritual life. The most important role in formation and the subsequent preservation of the Russian spiritual heritage is occupied by art. Traditions of domestic culture rely on values which are global, significant on state level, even in spite of the fact that Russian values can be opposite to ideas of the modern West: "the culture of our Fatherland was formed in the conditions of huge spaces, remoteness of settlements, instability of weather conditions... It created a special line of culture of the Russian ethnos which for centuries developed the habits, values and technologies suitable for our conditions. That is why the "superior" western culture may not always be "superior" under our conditions" [1, page 31]. In the contemporary culture of our country one of the major processes is not only preservation of its identity, but also search and creation of means which form the Russian cultural identity, introducing it to the cultural sphere of modern society and thereby directing the social life.

From all types of spirituality, in its understanding of cultures, sacral art most brightly reflects all depth of domestic cultures. It finds expression in wide fields painting, sculpturing, architecture, and also in music, literature, the modern film industry, etc. The artistic image in the Russian sacral art created by the most ancient traditions preserved the unique cultural style. These bases are unshakable despite the change of religious systems. The close relationship between art and spirituality is practically the root of all types of creativity.

Phenomenal is the fact that the religion already influences scientific knowledge of the world, and therefore is the spiritual sphere reflected in sacral art a result of a choice taken by several people. The number of people connecting their life with spiritual education only increases in our country. Thus Russia can't, in this regard, be compared to other countries. For example, many Arab states already put religious education into work on a state level. Russia, free- thinking as it is, grants each personality options, and often this choice is made towards a spiritual model of a way of life.

Today, during the revival of spiritual ethics and the formation of new sacral understanding in art there are a number of questions, brought up by the research of sociologists, culturologists and art critics, that deserve attention. What represents sacral art in the modern world? What are signs and symbolical forms and ways of further development? Why is sacral art capable of influencing the formation of the Russian cultural identity and positive national qualities? Why can sacral art be taken as an example in the cultural life of society?

\section{SACRAl ART IN THE CUlture OF THE COUNTRY}

As a rule, by considering the questions mentioned above connected with sacral art, two points of view are allocated for the condition of a spiritual model in education and a tendency of development of sacral art. The first sees in sacral art a tendency to revive the best traditions of domestic culture, and predicts as a result the birth and strengthening of new current trends in art creativity. The second, on the contrary, judges modern spiritual culture as insufficient, considering it a weak imitation of the heritage of past centuries and a commercial product with superficial spiritual contents. Of course, both that and other points of view are worth considering, but this paper will be focused on the first opinion as prevailing is an ethical aspect of sacral art.

The sensual knowledge which is perceived by the personality at the aesthetic level is embodied in sacral art. And if the culture can be divided conditionally in aristocratic and national, elite and mass, the spiritual sphere, on the contrary, doesn't differentiate between these factors. Sacral art does quite the opposite: it unites various occupation layers in society.

Speaking about art it is necessary to mention the fact that any type of art has the means of expression and materials. For example, each Russian Orthodox church can be considered a synthesis of art forms such as architectural construction, sculptural images, bas-reliefs, mosaics and iconography. All created images reveal the author through a prism of art interpretation. Art interpretation isn't feasible without an author's creativity and a painter with a certain spiritual outlook.

As striking example are the works of the great Russian icon painter Andrei Rublyov who, as we know, was a monk in the Andronikov Monastery in Moscow. Rublyov's works 
belong to the highest achievements of the Russian and international spiritual art which embodied sublime understanding of spiritual beauty and moral strength of the people of Sacred Russia. An icon "Trinity" - the masterpiece created in to. XIV - the N of the XV century, is filled with deep poetic and philosophical contents. The main idea of "Trinity" is self-sacrifice as the highest condition of the spirit creating harmony worldwide and in everyday life. The greatest masters of Old Russian painting, including Dionysius, were deeply influenced by his creativity. In 1551 in the Stoglavy cathedral, Rublyov's iconography was proclaimed a sample for imitation. And to this day a great number of masters of the modern icon-painting school imitate the skills of Andrei Rublyov. To create art as great as his it is said that it "[is] respectively important to not only have knowledge of the Russian spirituality as a specific intellectual fund of human culture..., but first of all, to have knowledge of valuable, personal installations, a spiritual power which made features of organization of an interior, a special system of his consciousness ..." [2, page 11]

But it is a concrete example of church painting which is already initially ranked as sacral art. However, in secular art, through interpretation of the artistic images created by the artist we can also see a sacral component. The question and in whose images it is transferred depends only on what sacrality of a plot is intended by the artist. A sculpture and a painting devoted to the Great Patriotic War can serve as an example. The picture "Defense of Sevastopol" of Deyneki or Toidze's poster "the Motherland calls!". The images created by artists are a symbol of self-sacrifice and heroism, images sacred to the Russian people.

The well-known artist of the Soviet era K.S. PetrovVodkin in the famous picture "Petrograd Madonna" combines obviously opposite subjects, difficulties of civil war and motherhood. In this case the spiritual image of the Petrograd Madonna is a peculiar interpretation of an icon image of the Mother of God, a Madonna with the baby in cloths typical for a European painting, turning the young worker into a symbolical image of motherhood. The kerchief on the head of the heroine is a characteristic sign of that time, like the one the women working for machines carried. At the same time the kerchief in a picture causes associations with the classical drapery covering the Madonna's head. The Petersburg Madonna seems to be passing through all sphere of the spiritual heritage of art. The artist, equalizing motherhood of the simple woman and Madonna, creates a sacral image of a female mother in this era.

\section{SACRAL ART - A MODEL OF FORMATION OF CULTURE IN SOCIETY}

Today it is obvious that the world entered a new era which is called globalization. On the one hand recognitions of separate nationalities as world supremacy were proved wrong, on the other hand, there is still a big need for close cooperation of all ethnicities.

Today the national state can rely only on the understanding of the national community. The ethnic identity of each individual leads to uniform association with the moral norms celebrated by the traditions accepted in society.
All associations, since a family, the smallest and most main human group, always depend on each certain person entering association. It is created and approved in separate consciousness, and the sociocultural model, which is a moral reference point of all those values which allow society to exist in its present cultural state, is embodied then. The sociocultural model creates all those forms which define the ethical views of the individual, defines the direction in which the society in which this individual exists will move as "it is obvious that if there is no independent philosophy, it is rather difficult to formulate both national consciousness, spiritual ideals and criteria of moral" [2, page 45]. Therefore, sacral art is an important tool for the formation of an ethnocultural identity and the maintenance of an appreciation of native history and national values. In this case the cultural language of art puts a focus on the person, relying both on art values and on the ethical standards forming civil society and behavior of this society in their country, as "pictures on religious subjects can serve reminiscence and learning" [3, page 111]. It stands behind the created sociocultural model much more important than the general report of the norms and rules of conduct accepted in society because it covers a certain norm not only for the individual, but also for personal relations between different people. The process of a sacralization in art acts as an effective remedy of the organization of social life as it is connected with the formation of fundamental standard norms in society defining semantics of cultural forms, moral ideals and human motives.

In domestic art, in its various art forms created by national traditions with the sacral images put in the course of creation, the individual beholds since the most ancient times the worldview presented by the author. The artist can specify, change or anew retell this or that spiritual plot, passing on experience of generations. Art develops all new traditions, but on the basis of the old. We already see here that art produced by national foundations is an important distinctive sign of ethnos and in its structure bears features of understanding of the world and moral values of the people. As far as this structure precisely reflects a worldview, it is the question demanding detailed discussion, but the important role of art in this process isn't denied by anybody.

\section{REFERENCES}

[1] L. N. Dorogova. General theory of culture. - M, 2008

[2] E. N. Seleznyova, A. V. Kamenets. Cultural science of the Russian world: historiosophical and spiritual and moral bases of national mentality. - M, 2012

[3] A.S. Hudoshin. Art and Orthodoxy. - M, 2004. 